Bond University

Research Repository

\title{
More than merely work-ready: Vocationalism versus professionalism in legal education
}

\author{
James, Nickolas
}

Published in:

University of New South Wales Law Journal

DOI:

10.53637/CMUH5822

Link to output in Bond University research repository.

Recommended citation(APA):

James, N. (2017). More than merely work-ready: Vocationalism versus professionalism in legal education. University of New South Wales Law Journal, 4O(1), 186-209. https://doi.org/10.53637/CMUH5822

\footnotetext{
General rights

Copyright and moral rights for the publications made accessible in the public portal are retained by the authors and/or other copyright owners and it is a condition of accessing publications that users recognise and abide by the legal requirements associated with these rights.

For more information, or if you believe that this document breaches copyright, please contact the Bond University research repository coordinator.
} 


\section{Bond University}

2017

More than merely work-ready: Vocationalism versus professionalism in legal education

Nickolas J. James

Bond University, Nick_James@bond.edu.au 


\title{
MORE THAN MERELY WORK-READY: VOCATIONALISM VERSUS PROFESSIONALISM IN LEGAL EDUCATION
}

\author{
NICKOLAS J JAMES*
}

\section{INTRODUCTION}

This article offers a critique of the dominance of vocationalism within contemporary Australian legal education, and a strategy for challenging that dominance. 'Vocationalism' is an educational philosophy or approach to teaching that claims the content of the curriculum must be governed by its occupational utility. In the context of legal education, it is the notion that what is taught in the law school, and how it is taught, must be determined primarily by its consistency with the goal of student employability. In other words, it is the notion that the principal purpose of legal education is preparing law students to be lawyers. A particular law school may define vocationalism broadly or narrowly: the emphasis may be upon preparing law students to be a particular type of lawyer such as a commercial lawyer, or any type of lawyer, or a graduate with legal knowledge and skills able to be applied in any of a wide range of professions. In all cases, it is the employability of graduates that is paramount.

The dominance of vocationalism within contemporary legal education - and within higher education generally - is readily apparent. Governments frequently emphasise the importance of universities contributing to graduate employability and producing graduates capable of making substantial contributions to national productivity. ${ }^{1}$ Universities and law schools promote themselves to prospective students by emphasising their employability rates and the starting salaries of their graduates. ${ }^{2}$ Scholarship about curriculum reform frequently emphasises the importance of embedding practical skills within the law curriculum to ensure law

\footnotetext{
* $\quad$ Professor and Executive Director, Centre for Professional Legal Education, Faculty of Law, Bond University.

1 See, eg, recent public commentary by the Federal Minister for Education: Simon Birmingham, 'Speech at Ai Group Launch of Graduate Employment Service' (Speech delivered at the Ai Group Launch of Graduate Employment Service, Canberra, 11 October 2016) <http://www.senatorbirmingham.com.au/ Latest-News/ID/3244/Speech-at-Ai-Group-launch-of-Graduate-Employment-Service>.

2 Margaret Thornton and Lucinda Shannon, “Selling the Dream': Law School Branding and the Illusion of Choice' (2013) 23 Legal Education Review 249, 257-65.
} 
students are adequately prepared for legal practice. ${ }^{3}$ Legal education scholarship abounds with examples of ways the law curriculum can be made more practical, clinical and authentic, ${ }^{4}$ and law student employability can be enhanced. ${ }^{5}$ The vocational approach to teaching law is so widely advocated today that it appears to be taken for granted by many participants within the legal education enterprise that law schools exist primarily to educate the next generation of lawyers.

It is the contention of this article that vocationalism's dominance is problematic. The article is certainly not alone in this regard: there are many legal education scholars, academics and commentators who have challenged the emphasis upon employability within contemporary legal education. ${ }^{6}$ Critics point to the dilution of academic rigour, the exclusion of non-vocational but nevertheless valuable content from the curriculum, the encouragement of law students to focus upon extrinsic motivators, and the implicit adoption of a sociopolitical position that favours the status quo and ignores the potential for law graduates to participate in legal and social reform. ${ }^{7}$ When the primary emphasis is upon employability, and the majority of a law school's time, attention and resources are directed to that end, other important elements of legal education are disregarded, and the law school fails to achieve its full potential.

Like all dominant discourses, the dominance of vocationalism can be subverted. Rather than direct confrontation and overt criticism of vocationalism, however, this article advocates a subtler strategy. Those critical of vocationalism's dominance - referred to in this article as 'V-sceptics' - should appropriate the concept of 'professionalism'. They should participate willingly in vocational initiatives, but argue in favour of preparing law students to be not merely legal employees, but legal professionals. And they should promote a concept of professionalism that is broad enough and inclusive enough to require incorporation within law curricula of elements traditionally excluded by vocational initiatives.

3 See, eg, the focus upon different approaches to embedding practical skills in Richard Johnstone and Sumitra Vignaendra, 'Learning Outcomes and Curriculum Development in Law' (Report, Australian Universities Teaching Committee, Department of Education, Science and Training, 2003) 166.

4 Recent examples include Tammy Johnson and Francina Cantatore, 'Equipping Students for the Real World: Using a Scaffolded Experiential Approach to Teach the Skill of Legal Drafting' (2013) 23 Legal Education Review 113; Carolyn Penfold, 'Developing Legal Communication Skills in a South Pacific Context' (2014) 24 Legal Education Review 115; Jane Ching, "“Favourable Variations”: Towards a Refreshed Approach for the Interviewing Classroom' (2015) 25 Legal Education Review 173; Katherine Curnow, 'More than the Rules: Using Pleading Drafting to Develop Lawyering and Transferable Skills' (2015) 25 Legal Education Review 203.

5 Recent examples include Madeleine Fraser et al, 'Transition from Legal Education to Practice: ExtraCurricular Competitions Offer the Missing Link’ (2013) 23 Legal Education Review 131; Amanda Kennedy et al, 'Educating Law Students for Rural and Regional Legal Practice: Embedding Place Consciousness in Law Curricula' (2014) 24 Legal Education Review 6; Duncan Bentley and Joan Squelch, 'Employer Perspectives on Essential Knowledge, Skills and Attributes for Law Graduates to Work in a Global Context' (2014) 24 Legal Education Review 93; Judith McNamara et al, 'Capstones as Transitional Experiences' (2015) 25 Legal Education Review 7.

6 Contemporary critics include Margaret Thornton and many of the authors who contributed to the recent 2013 special issue of the Legal Education Review including Mary Heath, Peter Burdon, Paula Baron and Frank Carrigan.

7 Each of these criticisms is examined below. 
This article explains and justifies the various elements of this strategy. Part II describes vocationalism's dominance in more detail, and identifies some of the reasons for that dominance. Part III identifies the main reasons why vocationalism's dominance is seen by many to be problematic. Part IV explains the notion of 'appropriation', a central element of the strategy advocated in this paper. Part $\mathrm{V}$ examines the range of possible definitions of the term to be appropriated: 'professionalism'. Part VI is an examination of the potential benefits of appropriating professionalism in order to challenge vocationalism's problematic dominance of legal education.

\section{VOCATIONALISM'S DOMINANCE}

'Vocationalism' is defined in this article as an educational philosophy or approach to teaching that insists that the content of a curriculum must be governed by its occupational utility. In the context of legal education, it is the notion that the principal purpose of legal education is preparing law students to be lawyers.

Vocationalism is hardly a new idea within the law school. When law was first taught in Australia in the earliest law schools, it was taught in a vocational manner. Classes were delivered by practitioners to students who were themselves typically employed in law firms as clerks and trainees, with classes taught in the evenings after both teachers and students had spent the day engaged in the practice of law. ${ }^{8}$ The content of these early law subjects of course focussed upon practical legal processes and issues. It was not until the period following World War II that a new type of lawyer emerged: full-time legal academics who sought to distinguish themselves from their practising colleagues by adopting a new approach to teaching and writing about law, one that emphasised doctrines and principles rather than skills and procedures. ${ }^{9}$ Over the next few decades the gap between the legal academy and the practising profession widened, until by the 1980s legal education had very little to do with legal practice, and the curricula of most Australian law schools were almost entirely doctrinal with little room for either skills development or critique of the law. ${ }^{10}$

The trend began to reverse in the late 1980s, a transition phase marked by the publication of the Pearce Report and its insistence that more attention be paid by law schools to the preparation of law students for legal practice post-graduation. ${ }^{11}$ In 1999, the Australian Law Reform Commission contributed to the trend back towards vocationalism when it insisted that legal education should focus on what

8 Linda Martin, 'From Apprenticeship to Law School: A Social History of Legal Education in Nineteenth Century New South Wales' (1986) 9(2) University of New South Wales Law Journal 111, 121, 135-6.

9 Judith Lancaster, The Modernisation of Legal Education: A Critique of the Martin, Bowen and Pearce Reports (Centre for Legal Education, 1993) 2.

10 See Nickolas John James, 'Expertise as Privilege: Australian Legal Education and the Persistent Emphasis Upon Doctrine' (2004) 8 University of Western Sydney Law Review 1, 6.

11 Dennis Pearce, Enid Campbell and Don Harding, Australian Law Schools: A Discipline Assessment for the Commonwealth Tertiary Education Committee (Australian Government Publishing Service, 1987). 
lawyers need to be able to do, rather than on what lawyers need to know, and recommended that

[i]n addition to the study of core areas of substantive law, university legal education in Australia should involve the development of high level professional skills and a deep appreciation of ethical standards and professional responsibility. ${ }^{12}$

Since then, the gap between the academy and the practising profession has continued to narrow, and the vocational approach to legal education has once again become the dominant approach. ${ }^{13}$ Evidence of vocationalism's dominance can be found within almost every aspect of legal education. The structure of every Bachelor of Laws ('LLB') and Juris Doctor program in Australia prioritises law student employability by ensuring that students are obliged - or at least have the opportunity ${ }^{14}$ - to complete the eleven areas of knowledge required to satisfy the academic requirements for admission as a legal practitioner. ${ }^{15}$ Most law schools include within their lists of program learning outcomes the development by students of competence in the exercise of practical legal skills, and have incorporated skills development programs into their curricula. In 2003, Johnstone and Vignaendra described the infusion of legal skills education and training into LLB programs as 'the biggest change in law school curricula over the previous decade'. ${ }^{16}$ Many law schools provide their students with the opportunity to engage in clinical legal education by volunteering (or participating for course credit) in law clinics and community legal centres, or to acquire practical legal experience by participating in internships and placements. ${ }^{17}$ When law schools describe their own priorities and activities in their mission statements and on their websites, they tend to emphasise those elements that highlight the connections between legal education and legal practice: their close relations with members of the profession, their practical approach to teaching law, their graduate employment rates and their graduate starting salaries. ${ }^{18}$

Vocationalism's dominance is also evident in contemporary legal education scholarship. A significant proportion of academic journal articles published in recent years within the specialised field of legal education have focussed

12 Australian Law Reform Commission, Managing Justice: A Review of the Federal Civil Justice System, Report No 89 (2000) 153.

13 Nickolas John James, 'Why Has Vocationalism Propagated So Successfully within Australian Law Schools?' (2004) 6 University of Notre Dame Australia Law Review 41.

14 Prior to 2017 at the University of Queensland, for example, some of the 'Priestley 11' topics were located in elective subjects rather than compulsory subjects: The University of Queensland, Bachelor of Laws (Honours) Course List $2016<\mathrm{http}: / / w w w . u q . e d u . a u / s t u d y /$ program_list.html?acad_prog=2359\& year $=2016>$. In the author's experience, nearly every law student chose to enrol in those elective subjects.

15 The eleven areas of knowledge are Contract Law, Tort Law, Real and Personal Property Law, Equity (including Trusts), Criminal Law and Procedure, Civil Procedure, Evidence, Professional Conduct, Administrative Law, Federal and State Constitutional Law, and Company Law. These are known as the 'Priestley 11': Consultative Committee of State and Territorial Law Admitting Authorities, 'Uniform Admission Requirements: Discussion Paper and Recommendations' (Report, 1992) 24-5.

16 Johnstone and Vignaendra, above n 4, 166.

17 For an overview of clinical legal education in Australia see Adrian Evans et al, 'Best Practices Australian Clinical Legal Education' (Report, Australian Government Office for Learning and Teaching, 2012).

18 Thornton and Shannon, above n 3, 257-65. 
upon vocational aspects of legal education. The three most recent volumes of the Legal Education Review (Volume 23 in 2013, Volume 24 in 2014 and Volume 25 in 2015) saw the publication of a total of 31 general legal education articles. Of these 31 articles, 15 had an overtly vocational emphasis including 4 articles explicitly about preparing law students for legal practice, ${ }^{19} 4$ articles about teaching practical legal skills, ${ }^{20} 4$ articles about teaching ethics and professionalism, ${ }^{21}$ and 3 articles about clinical legal education..$^{22}$

The emphasis upon vocationalism and employability within legal education is a reflection of vocationalism's dominance in discourse about higher education generally. The employability of university graduates is a common topic within higher education research and scholarship. ${ }^{23}$ Higher education policies are very much concerned with the employability of graduates and the contribution by universities to economic performance through the creation of a productive graduate workforce. ${ }^{24}$ The 2002 Employability Skills for the Future report, for example, noted that

$[\mathrm{m}]$ ore than ever before universities are being relied upon as a vehicle for advancement of the national economy and wider society. They do this through the creation of new knowledge and by preparing graduates with appropriate skills and attributes. ${ }^{25}$

19 Madeleine Fraser et al 'Transition from Legal Education to Practice: Extra-Curricular Competitions Offer the Missing Link' (2013) 23 Legal Education Review 131; Amanda Kennedy et al, 'Educating Law Students for Rural and Regional Legal Practice: Embedding Place Consciousness in Law Curricula' (2014) 24 Legal Education Review 6; Duncan Bentley and Joan Squelch, 'Employer Perspectives on Essential Knowledge, Skills and Attributes for Law Graduates to Work in a Global Context' (2014) 24 Legal Education Review 93; Judith McNamara et al, 'Capstones as Transitional Experiences' (2015) 25 Legal Education Review 7.

20 Johnson and Cantatore, above n 5; Penfold, 'Developing Legal Communication Skills in a South Pacific Context', above n 5; Ching, above n 5; Curnow, above n 5.

21 Carolyn Penfold, 'Teaching Legal Ethics and Professionalism in a South Pacific Context' (2013) 23 Legal Education Review 7; Magdalene D'Silva, 'A New Legal Ethics Education Paradigm: Culture and Values in International Arbitration' (2013) 23 Legal Education Review 83; Lesley Townsley, 'Thinking like a Lawyer Ethically: Narrative Intelligence and Emotion' (2014) 24 Legal Education Review 68; Maria Nicolae, 'Legal Education, Legal Practice and Ethics' (2015) 25 Legal Education Review 237.

22 Susannah Sage-Jacobson and Tania Leiman, 'Identifying Teaching and Learning Opportunities within Professional Relationships between Clinic Supervisors' (2014) 24 Legal Education Review 156; Rachel Spencer and Matthew Atkinson, 'Towards a Pedagogy of the Integration of Clinical Legal Education within the Law Curriculum: Using De-identified Clinic Files within Tutorial Programs' (2015) 25 Legal Education Review 121; Francina Cantatore, 'Boosting Law Graduate Employability: Using a Pro Bono Teaching Clinic to Facilitate Experiential Learning in Commercial Law Subjects' (2015) 25 Legal Education Review 147.

23 See, eg, Geoffrey William Hinchliffe and Adrienne Jolly, 'Graduate Identity and Employability' (2011) 37 British Educational Research Journal 563; Leonard Holmes, 'Competing Perspectives on Graduate Employability: Possession, Position or Process?’ (2013) 38 Studies in Higher Education 538; Peter Knight and Mantz Yorke, Learning, Curriculum and Employability in Higher Education (RoutledgeFalmer, 2004); Mantz Yorke, Employability in Higher Education: What It Is - What It Is Not (The Higher Education Academy, 2006) <https://www.heacademy.ac.uk/node/3263>; Mantz Yorke and Peter T Knight, 'Curricula for Economic and Social Gain' (2006) 51 Higher Education 565.

24 Belinda Robinson, 'Strong Tertiary Sector the Engine Room of Australia's Prosperity', The Australian (online), 1 June $2016<\mathrm{http}$ //www.theaustralian.com.au/higher-education/opinion/strong-tertiary-sectorthe-engine-room-of-australias-prosperity/news-story/94e1b536f7b59d01eb951f1f34237c60>.

25 Commonwealth Department of Education, Science and Training, 'Employability Skills for the Future' (Report, March 2002) 25. 
The vision for higher education articulated in the 2008 Bradley Review emphasised the production of 'graduates with the knowledge, skills and understandings for full participation in society as it anticipates and meets the needs of the Australian and international labour markets'. ${ }^{26}$ The Australian Government's 2016 discussion paper, Driving Innovation, Fairness and Excellence in Australian Higher Education, emphasises the employability of graduates in its description of the benefits of a strong higher education system:

For students, higher education supports entry into the workforce, access to skilled employment, higher salaries and lifetime earnings, and greater career flexibility. For business and industry it delivers skills, research partnerships, new product ideas and innovation in practices. For the wider community, it enriches our cultural landscape, upholds our standard of living, provides an evidence base to inform public debate and is a source of innovation and development across our regions. Higher education also contributes to society in other ways, including through increased tax revenues generated by a highly skilled workforce, and better access to professional services. ${ }^{27}$

Public commentary and debate about the role and the effectiveness of universities tend to focus upon the extent to which a university education contributes to a graduate's employability. ${ }^{28}$

An emphasis upon employability is not only consistent with the apparent expectations of the community and the government: the students themselves have very clear expectations that their university studies will assist them to get a job. As John Goldring observes:

many law teachers ... believe that they have an obligation to their students not to depart too radically from accepted modes of legal education. For some, this is because they consider that their task is to provide the students with what the students expect: a course of studies which will be the basis for a career in legal practice. Others fear that if they do not, students will not seek to enter their law schools. ${ }^{29}$

This is especially so when students are paying substantial fees to study at university, and expect the outcomes of their time at university to include an advantage when applying for positions that will allow them to comfortably repay their student debts. University leaders and administrators, concerned to ensure that their programs are marketable and that their paying customers are satisfied with the educational product, almost inevitably expect law schools to respect law student preferences and vocationalise their programs. ${ }^{30}$

26 Denise Bradley et al, 'Review of Australian Higher Education: Final Report' (Report, Department of Education, Employment and Workplace Relations, December 2008) 6.

27 Australian Government, 'Driving Innovation, Fairness and Excellence in Australian Higher Education' (Report, May 2016) 3.

28 See, eg, Andrew Trounson, 'Grim Jobs Outlook for New Graduates' The Australian (online), 24 July $2015<$ http://www.theaustralian.com.au/higher-education/grim-jobs-outlook-for-new-graduates/newsstory/3d6a774ebb995dc9ba3f178c721d50d5>; Hamish Coates, 'Employability: Time For Higher Education Sector to Step Up', The Australian (online), 25 November $2015<\mathrm{http} / /$ www.the australian.com.au/higher-education/opinion/employability-time-for-higher-education-sector-to-stepup/news-story/bf2846cd3079752a796fc5981f9a239c>.

29 John Goldring, 'Tradition or Progress in Legal Scholarship and Legal Education' in John Goldring, Charles Sampford, and Ralph Simmonds (eds) New Foundations in Legal Education (Cavendish Publishing, 1998) 47.

30 See generally Margaret Thornton, Privatising the Public University: The Case of Law (Routledge, 2012). 
A vocational approach to teaching law is also consistent with the expectations of employers and the legal profession generally. ${ }^{31}$ The legal profession has for many years insisted that law schools should do more to ensure that law graduates are prepared for professional practice, and they have influenced law school policy and practice through participation on advisory boards and direct lobbying of Deans. ${ }^{32}$ Professional bodies such as the Law Admissions Consultative Committee ('LACC') and the various state admission authorities endeavour to exert considerable influence over law schools and their decisions about what is to be included in the law curriculum. It is the admission authorities that insist that all law graduates seeking admission as legal practitioners demonstrate completion of the 'Priestley 11' prescribed areas of knowledge, thereby ensuring that all law schools include those areas of knowledge in their curricula. ${ }^{33}$ More recently, LACC's proposed Accreditation Standards for Australian Law Courses seek to regulate not only the content of the units required for admission, but also the duration of the degree, the program learning outcomes, the teaching methods adopted and the assessment practices, all with the vocational objective of

assist[ing] an Admitting Authority, when accrediting, monitoring, reviewing or reaccrediting a law course, to determine whether that law course will provide for a student to acquire and demonstrate appropriate understanding and competence in each element of a prescribed area of knowledge ... and [in each element] ... of the LACC Statement on Statutory Interpretation. ${ }^{34}$

The vocational approach to teaching law is so widely advocated today that it is taken for granted by many legal academics, law students and commentators that law schools exist primarily to educate the next generation of lawyers. ${ }^{35}$

31 For example, according to law firm partner Greg Vickery: 'It has increasingly been recognised that undergraduate education should encompass at least some legal skills training which was largely ignored by traditional law schools apart from the limited practical skill of mooting ... This has greatly assisted in overcoming what I have perceived to be a major difficulty with law schools in the past: that law graduates traditionally had considerable difficulty in adapting their substantive legal knowledge to the working environment': 'The Legal Profession and the Expansion of Law Schools in Australia' in John Goldring, Charles Sampford, and Ralph Simmonds (eds), New Foundations in Legal Education (Cavendish Publishing, 1998) 212, 213-4.

32 Andrew Goldsmith and David Bamford, 'The Value of Practice in Legal Education' in Fiona Cownie (ed), Stakeholders in the Law School (Bloomsbury Publishing, 2010). As one Australian Law Dean explains: 'We've acceded absolutely. We've tugged the forelock to the profession, and I think this is another reason for actually dumbing down what's happening within the law schools now by, again, subsuming the PLT [Practical Legal Training] within the curriculum. ... I think someone's talked about a sort of relationship with feudalism between the law school and the legal profession and that we owe this fealty and until we actually break that, sever that, then we will not really be an intellectual discipline within the university': Johnstone and Vignaendra, above n 4, 161.

33 According to Goldsmith, the Priestley 11's influence 'upon the entire LLB curriculum is indisputable, and lends legitimacy, and some persuasive force, to the pattern of teaching confined to legal exposition leavened perhaps by a little policy': Andrew Goldsmith, 'Legal Education and the Public Interest' (1998) 9 Legal Education Review 143, 150-1.

34 Law Admissions Consultative Committee, 'Accreditation Standards for Australian Law Courses' (13 October 2016) 6.

35 A legal education that fails to provide students with the knowledge and skills needed for a successful career in law is portrayed as fundamentally flawed. See, eg, Katherine Towers, 'Law Graduates Not Keeping Up with the Modern World', The Australian (online), 25 May $2016<$ http://www.the 
Vocationalism's dominance is however questioned, challenged and opposed by 'V-sceptics', who insist that the law school has a role to play beyond the training of lawyers.

\section{CHALLENGING VOCATIONALISM'S DOMINANCE}

An inappropriate emphasis upon employability is not the only ground for criticism of contemporary legal education. Critics point to the low level of engagement by many law teachers with the scholarship of learning and teaching, ${ }^{36}$ the potentially harmful emphasis upon adversarialism, ${ }^{37}$ and the persistent emphasis within many of the more traditional law units upon legal doctrine in isolation from its professional, cultural and political contexts. ${ }^{38}$ There are some who insist that the relationship between the legal academy and the legal profession is not close enough, ${ }^{39}$ or that the content of the law curriculum is inadequately practice-focussed, ${ }^{40}$ although the assumptions implicit in these latter critiques - that the relationship should be close and the curriculum should be practice-focussed - are themselves consistent with vocationalism. The position taken in this article - and by V-sceptics generally - is that the dominance of vocationalism, although not the only problematic feature of contemporary legal education, is certainly one of the most significant ones, and is worthy of scrutiny and attempts to reform.

$\mathrm{V}$-sceptics do not necessarily question the inclusion within the curriculum of elements designed to prepare students for the workplace. Many law students do

australian.com.au/higher-education/law-graduates-not-keeping-up-with-the-modern-world/newsstory/e2092d31bd445d4418d623b3d16a7537>; Stefanie Garber, 'Law Students Question Value of Their Degree', Lawyers Weekly (online), 4 August $2015<$ http://www.lawyersweekly.com.au/news/16923-lawstudents-question-the-value-of-degree>; Linda Sheryl Greene, 'Law Schools Need to Better Prepare Their Students', The New York Times (online), 24 September $2015<\mathrm{http}$ //www.nytimes.com/roomfordebate/ 2015/09/24/is-the-bar-too-low-to-get-into-law-school/law-schools-need-to-better-prepare-their-students>.

36 See, eg, Brett Freudenberg, 'Show Me the Evidence: How the Scholarship of Learning and Teaching is Critical for Modern Academics' (2012) 7 Journal of the Australasian Tax Teachers Association 171; Nick James, “How Dare You Tell Me How to Teach!': Resistance to Educationalism within Australian Law Schools' (2013) 36 University of New South Wales Law Journal 779.

37 See, eg, James Duffy, 'Balance and Context: Law Student Well-Being and Lessons from Positive Psychology' in Rachael Field, James Duffy and Colin James (eds), Promoting Law Student and Lawyer Well-Being in Australia and Beyond (Routledge, 2016); Pauline Collins, 'Australian Legal Education at a Cross Roads' (2016) 58(1) Australian Universities' Review 30; Kathy Douglas, 'The Role of ADR in Developing Lawyers' Practice: Lessons from Australian Legal Education' (2015) 22 International Journal of the Legal Profession 71.

38 James, 'Expertise as Privilege', above n 11.

39 See, eg, M Weir, 'The Dissonance Between Law School Academics and Practitioners - The Why the How the Where to Now' (1993) 9 Queensland University of Technology Law Journal 143; David Weisbrot, Australian Lawyers (Longman Cheshire, 1990).

40 See, eg, Susan Daicoff, 'The Future of the Legal Profession' (2011) 37 Monash University Law Review 7. This critique is particularly prominent in the US: William M Sullivan et al, Educating Lawyers:

Preparation for the Profession of Law (Carnegie Foundation for the Advancement of Teaching, 2007); Roy Stuckey et al, Best Practices for Legal Education: A Vision and a Road Map (Clinical Legal Education Association, 2007); Stephen Gerst and Gerald Hess, 'Professional Skills and Values in Legal Education: The GPS Model' (2009) 43 Valparaiso University Law Review 513. 
in fact become lawyers, and very few $\mathrm{V}$-sceptics are calling for a return to the days of doctrinalism's dominance and a legal education that has nothing at all to do with preparation for legal practice. What they question, challenge and criticise is vocationalism's dominance. It is the dominance of the discursive field of legal education by a single discourse that is seen as problematic. ${ }^{41}$ Law teachers do not have unlimited time and law schools do not have unlimited resources. Choices must be made about what to include within, and what to exclude from, the law curriculum. Vocationalism's dominance results in the marginalisation and exclusion of non-vocational content: see Figure 1. When the employability of law graduates is positioned at the centre of the curriculum, the development of practical legal skills and the provision of clinical experiences is privileged alongside examination of fundamental legal rules and doctrines, but other important legal topics such as the history of law, theories of justice and rights, and jurisprudence are de-emphasised because their contribution to graduate employability is less obvious. Radical perspectives on the law such as feminist legal theory, critical legal theory, critical race theory, queer theory and the like are in danger of being excluded from the curriculum entirely.

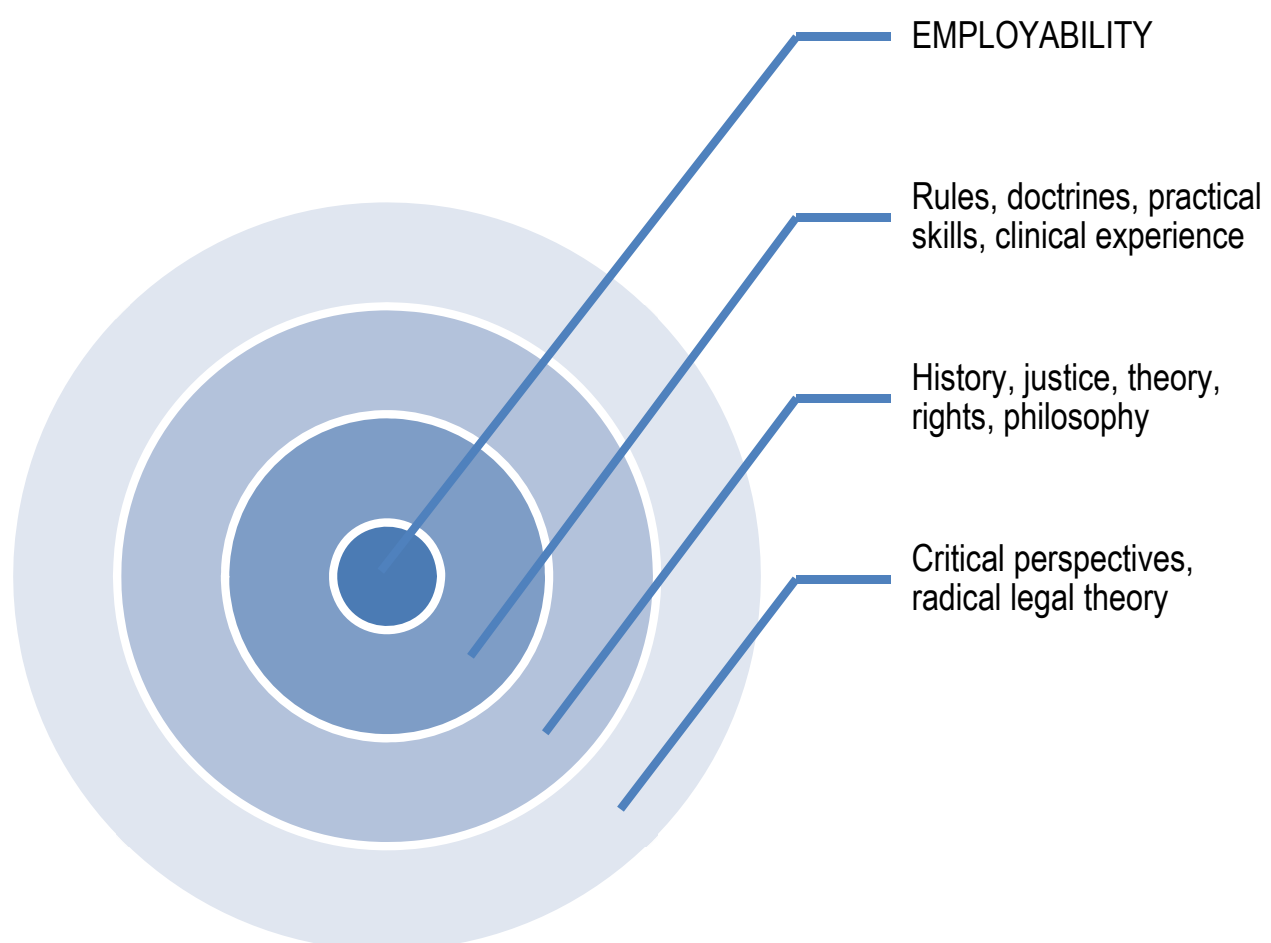

Figure 1: The consequences of privileging employability

41 Anthony O'Donnell and Richard Johnstone, for example, criticise vocationalism's dominance when they write that ' $[\mathrm{t}]$ he academic study of law [is] a serious endeavour in itself, rather than ... merely ... a training ground for future lawyers': Developing a Cross-Cultural Law Curriculum (Cavendish Publishing, 1997) 2. Judith Lancaster similarly argues that 'responsible universities have an obligation to develop something more in students than profit making acumen': 'In Favour of an Integrated Approach to the Teaching of Ethics to Business Law Students' (2001) 3 University of Technology Sydney Law Review 174, 174. 
If one accepts the pluralist premise that the existence of multiple competing discourses is preferable to the existence of a single dominant discourse, then vocationalism's dominance must be recognised as problematic. Ideological dominance is always problematic because it leads to the silencing of alternative voices.

It is also important to recognise that V-sceptics challenge vocationalism's dominance for a variety of reasons. V-sceptics favour a variety of competing discourses and it would be a mistake to see them as a homogenous group. ${ }^{42}$ Some $\mathrm{V}$-sceptics favour a more 'traditional' doctrinal or theoretical curriculum, some are concerned about the student experience and student wellbeing, some favour a broad liberal legal education over a narrow vocational one, and some seek to unlock the potential for law schools to produce graduates determined to combat injustice, inequality, and discrimination. Some of these V-sceptical positons are mutually exclusive. The proponents of these opposing positions are, however, united in their concern that vocationalism has become too dominant in contemporary legal education.

The various opposing viewpoints can be drawn upon to identify four main (and not necessarily consistent) criticisms of vocationalism and its contemporary discursive dominance.

\section{A Loss of Theoretical Rigour}

Vocationalism insists that law schools include in the limited law curriculum additional subjects focussing upon preparation for practice, and that law teachers include within their own law subjects information about the technical operation of law and an increased emphasis upon the teaching and assessment of practical legal skills. This means that there is less time spent examining the very complex and detailed nuances of legal regulation and legal doctrine. Some V-sceptics see this as leading to a loss of academic and intellectual rigour within law subjects, and a 'dumbing down' of the law degree. William L Twining wrote in 1993:

It is very doubtful whether compiling lists of discrete skills that practitioners say they think are important goes very far in the direction of a sound sociology of law ... the outcome to date seems to be longer and longer check-lists, with little analysis of interconnections and only rather primitive efforts at setting priorities. The almost inevitable result is the sacrifice of detail, depth and transferability to the dragon of "coverage" - in this case coverage of longer and longer lists in the name of a mechanistic form of bureaucratic rationalism that is threatening to engulf legal education. ${ }^{43}$

As explained earlier, one of the consequences of vocationalism's rise to dominance is an increased emphasis upon clinical learning experiences within the law curriculum. Proponents of clinical legal education argue that

42 As Michael Foucault insists, 'we must not imagine a world of discourse divided between accepted discourse and excluded discourse, or between the dominant discourse and the dominated one; but as a multiplicity of discursive elements that can come into play in various strategies': 'The Order of the Discourse' in Robert Young (ed), Untying the Text: A Post-Structuralist Reader (Routledge \& Kegan Paul, 1981) 50.

43 William L Twining, 'The Idea of Juristic Method: A Tribute to Karl Llewellyn' (1993) 48 University of Miami Law Review 119, 146. 
the incorporation of clinical experiences within the law curriculum does more than enhance the employability of law students. According to Redding, 'the often unrealized potential of clinics is that they can foster in students a better understanding and appreciation of the legal theory and analysis that is the mainstay of their doctrinal counterpart'. ${ }^{44}$ The 2012 report Best Practices Australian Clinical Legal Education identifies a range of benefits flowing from clinical legal education, only some of which are of vocational relevance. According to the report, clinical legal education has the potential to:

- help students reflect on and analyse their experiences;

- develop student awareness of law in the context of society;

- engage students in deep and active learning, with timely, rich feedback;

- develop student emotional skills, values, responsibility, resilience, confidence, self-esteem, self-awareness and humility;

- move a student towards responsible professional identity;

- sensitise students to the importance of all relationships - including with clients, students, professionals;

- benefit from student-centred learning, which comes out of flexible and adaptable approaches; and

- educate students to become effective, ethical practitioners. ${ }^{45}$

However, while clinical legal education has the potential - when implemented appropriately - to serve as a framework for deep theoretical examination of legal doctrine and policy, it also has the potential to contribute to marginalisation of such theoretical examination by shifting the focus to more practical and pragmatic aspects of the law. ${ }^{46}$

\section{B Loss of Curricular Breadth}

Other V-sceptics are less concerned with the loss of doctrinal detail than with the loss of curricular breath. They see the law degree as a degree that should provide law students with a broad liberal education rather than a narrow vocational education. ${ }^{47}$ While again acknowledging the potential for appropriately designed clinical legal education to incorporate development of 'student awareness of law in the context of society', ${ }^{48}$ an increased emphasis upon practical legal experience and preparation for employment can also lead to an inadequate emphasis upon topics that contribute to the creation of rational, cultured and broadly educated graduates. This includes topics that are of indirect relevance to employability such as the rule of law, liberal democratic principles,

44 Richard E Redding, 'The Counterintuitive Costs and Benefits of Clinical Legal Education' (2016) Wisconsin Law Review Forward 55, 62.

45 Adrian Evans et al, Best Practices Australian Clinical Legal Education (Australian Government Office for Learning and Teaching, 2012) 5.

46 Margaret Thornton, 'Among the Ruins: Law in the Neo-Liberal Academy' (2001) 20 Windsor Yearbook of Access to Justice 3.

47 Margaret Thornton has described the liberal approach to education as characterised by an apparent love of knowledge for its own sake, and a belief that universities be autonomous and not dictated to by agencies of the state: Margaret Thornton, 'The Idea of the University and the Contemporary Legal Academy' (2004) 26 The Sydney Law Review (Special Issue) 481. 
the relationship between law and politics, rights theory, theories of justice, jurisprudence and philosophy, and the rich history of law and of our legal system. Sir Anthony Mason, for example, criticised the impact of vocationalism when he warned:

Law schools must resist the temptation to become business schools, deferring to the demands of large commercial practices and ignoring consideration of intellectually demanding questions posed by the traditional subjects as well as the large and enduring jurisprudential issues relating both to the structure of legal systems and to the law's role in society. ${ }^{49}$

Non-legal scholars have also been concerned with such issues for a very long time. Cardinal John Henry Newman in his book The Idea of a University, first published in 1852, acknowledged that the training of professional people came within the function of a university, but insisted that the education of the intellect was the essential function of a university. ${ }^{50}$

\section{Over-emphasis upon Extrinsic Motivation}

If enhanced employability is positioned as one of the most important outcomes of legal education, then law students are encouraged to make - or to continue to make - employment their main motivation for studying law in the first place. Employment is an extrinsic motivation to learn; it is something beyond the direct control of the law student. ${ }^{51}$ It can be contrasted with an intrinsic motivation for studying law, such as a genuine interest in the academic study of law, or a desire to master the law in order to use that mastery to help others. There is reason to believe that law students who are extrinsically motivated are more likely to experience high levels of stress, anxiety and depression during their law studies than students who are intrinsically motivated. ${ }^{52}$ As such, the over-emphasis upon employability contributes to the high levels of psychological distress experienced by law students. ${ }^{53}$

49 Sir Anthony Mason, 'Universities and the Role of Law in Society' in John Goldring, Charles Sampford, and Ralph Simmonds (eds), New Foundations in Legal Education (Cavendish, 1998) x.

50 John Henry Newman, The Idea of a University Defined and Illustrated (Longmans Green, 1889). See also Huston Smith, The Purposes of Higher Education (Harper, 1955); Jacques Barzun, The House of Intellect (Harper, 1959).

51 Regarding extrinsic versus intrinsic motivations for learning, see Antonia Abbey, Christine DunkelSchetter and Philip Brickman, 'Handling the Stress of Looking for a Job in Law School: The Relationship between Intrinsic Motivation, Internal Attributions, Relations with Others, and Happiness' (1983) 4 Basic and Applied Social Psychology 263; Kennon M Sheldon and Lawrence S Krieger, 'Does Legal Education Have Undermining Effects on Law Students? Evaluating Changes in Motivation, Values, and WellBeing' (2004) 22 Behavioral Sciences and the Law 261.

52 Abbey, Dunkel-Schetter and Brickman, above n 52, 273-4; Sheldon and Krieger, above n 52, 268-9; Massimiliano Tani and Prue Vines, 'Law Students' Attitudes to Education: Pointers to Depression in the Legal Academy and the Profession?' (2009) 19 Legal Education Review 3, 3; Anna Huggins, 'Autonomy Supportive Curriculum Design: A Salient Factor in Promoting Law Students' Wellbeing' (2012) 35 University of New South Wales Law Journal 683.

53 See generally Norm Kelk et al, 'Courting the Blues: Attitudes Towards Depression in Australian Law Students and Lawyers' (Brain \& Mind Research Institute at the University of Sydney, 2009); Wendy Larcombe and Katherine Fethers, 'Schooling the Blues? An Investigation of Factors Associated with Psychological Distress among Law Students' (2013) 36 University of New South Wales Law Journal 390. 


\section{Favouring the Social and Political Status Quo}

V-sceptics who favour radical and critical approaches to legal education question vocationalism's implicit support for the professional, social and political status quo. Toddington, for example, criticises vocationalism's failure to distinguish between what legal skills ought to be and what legal skills are as practised, based upon an 'untheorised confidence in the infallibility of the practitioner'. ${ }^{54}$ An emphasis upon vocationalism leads to the training of law students to accept and fit in with the way things are currently done within the legal profession and within society generally. The US critical legal scholar Duncan Kennedy provocatively described vocational legal education as 'training for hierarchy':

Legal education structures the pool of prospective lawyers so that their hierarchical organization seems inevitable, and trains them in detail to look and think and act just like all the other lawyers in the system. ${ }^{55}$

Being employable often means understanding the importance of doing as one is told by one's employer. Lawyers have an enormous capacity to contribute to efforts to overturn the status quo in order to make the legal system and society generally more fair, more inclusive and more equitable, but effective legal and social reform is stifled if lawyers are only trained to be workers. ${ }^{56}$

There are many reasons to be concerned about and opposed to the dominance of contemporary legal education by vocationalism. The second half of this paper concerns the forms that opposition to vocationalism tends to take and whether that opposition is likely to be effective, and offers a strategy for challenging vocationalism by appropriating and widening the concept of 'professionalism'.

\section{IV 'APPROPRIATION'}

Given the value to university administrators of law schools as mechanisms for attracting high quality students to the institution, the vocal demands by students for qualifications that will lead to salaries generous enough to justify their university fees, and the ever closer ties between the academy and the practicing profession, the juggernaut of vocationalism is unlikely to stopped, or even slowed down, by its critics.

The traditional strategies used by $\mathrm{V}$-sceptics have not proven to be very effective in the face of vocationalism's impressive momentum. V-sceptics have written, and continue to write, scholarly papers and books highly critical of contemporary trends in legal education, ${ }^{57}$ but despite the fact that these works are

54 Stuart Toddington, 'Skills, 'Quality’ and the Ideologies of Managerialism' (1994) 28 Law Teacher 243, 255-6.

55 Duncan Kennedy, 'Legal Education as Training for Hierarchy' in David Kairys (ed), The Politics of Law: A Progressive Critique (Pantheon Books, $3^{\text {rd }}$ ed, 1998) 54, 72.

56 See generally Nickolas John James, 'The Marginalisation of Radical Discourses in Australian Legal Education' (2006) 16 Legal Education Review 55.

57 See in particular the work of Margaret Thornton, including Margaret Thornton, 'Portia Lost in the Groves of Academe Wondering What to Do about Legal Education' (1991) 9(2) Law in Context: A Socio-Legal 
frequently insightful, well researched, well written, and meticulous in their examination of vocationalism's failings, they appear to have done little to persuade the majority of law students, legal employers and universities to shift their focus away from employability. $\mathrm{V}$-sceptics might endeavour to engage in more direct action, and overtly challenge vocational approaches to curriculum design in law school staff meetings and as members of teaching and learning committees, but it seems that the more overt the opposition, the greater the likelihood of the academic being dismissed as unrealistic, out of step with contemporary trends in higher education, or even a political radical. ${ }^{58} \mathrm{~A} \mathrm{~V}$ sceptic might choose to autonomously and quietly de-emphasise employability within their own compulsory or elective law subject, but even if the academic was fortunate enough to get away with non-compliance with the university or school's vocational agenda, it would at best lead to a disharmonious curriculum. They might choose to explicitly question the emphasis upon employability in their own classes, challenging student preferences directly and endeavouring to persuade students to shift their focus and reassess their motivations, but unless done extremely tactfully there is a risk that this will lead to student animosity and reduced teaching evaluation scores. In extreme cases, a V-sceptic might even choose to leave the law school and relocate to another faculty such as justice studies or philosophy where they might be able to explicitly adopt non-vocational approaches to teaching and research about law, but they might instead discover that vocationalism is exerting an influence over those other faculties as well. ${ }^{59}$

This article offers an alternative strategy. V-sceptics should instead seek to 'hijack' vocationalism's momentum to achieve their own objectives. They should embrace the vocationalist notion that law schools should focus upon preparing their students for legal careers, and participate in - and thereby influence vocational initiatives with a view to creating law graduates who are not only 'work ready' but also theoretically informed, broadly educated, and concerned about social justice. This can be achieved by adopting and promoting an

Journal 9; Margaret Thornton, 'Law as Business in the Corporatised University' (2000) 25 Alternative Law Journal 269; Thornton, 'The Idea of the University and the Contemporary Legal Academy', above $\mathrm{n}$ 48; Margaret Thornton, Privatising the Public University, above n 31. See also the recent special issue of the Legal Education Review focusing upon critical approaches to legal education, including Thornton and Shannon, above n 3; Paula Baron, 'A Dangerous Cult: Response to 'The Effect of the Market on Legal Education"' (2013) 23 Legal Education Review 273; Gabrielle Appleby, Peter Burdon and Alexander Reilly, 'Critical Thinking in Legal Education: Our Journey' (2013) 23 Legal Education Review 345; Mary Heath and Peter D Burdon, 'Academic Resistance to the Neoliberal University’ (2013) 23 Legal Education Review 379.

58 Hillary Charlesworth quotes an article in the Australian Financial Review which argues that radical legal theorists should not be allowed to teach in law schools, because 'it is their avowed intention not to teach law in a way that will be useful to practitioners in the actual legal system'; that Critical Legal Studies (CLS) 'represents the loony Left of the legal profession'; and that its advocates 'have many of the features of a fundamentalist sect, being intolerant of democracy and willing to employ intimidation and misrepresentation': 'New Directions in Legal Theory: Critical Legal Studies' (1989) 63 Law Institute Journal 248, 248, quoting Padriac P McGuinness, 'The Trouble with Law School', Australian Financial Review, 1 February 1989.

59 W Norton Grubb and Marvin Lazerson, 'Vocationalism in Higher Education: The Triumph of the Education Gospel’ (2005) 76 The Journal of Higher Education 1. 
expanded notion of 'professionalism', one that incorporates all of these traits in what it means to be a legal professional.

The proposed strategy is based upon the notion of appropriation. Appropriation, in the sense used in this article, is the borrowing or adoption of a word or idea and using it in a manner inconsistent with its original meaning or purpose. It is similar to the notion of 'detournement', a technique developed by the Situationists in the 1950s. ${ }^{60}$ Detournement has been defined as '[turning] the expressions of the capitalist system against itself' ${ }^{61}$ An example of detournement is the use and alteration by subversive group Adbusters of imagery from Nike advertisements in order to draw attention to Nike's shifting of their production base to developing countries. ${ }^{62}$ Appropriation, then, is the act of taking a concept that is generally understood to have a particular meaning or significance that is contrary to one's own purposes, subtly redefining that concept so that it actually aligns with one's own purposes, and then actively promoting that redefined version of the concept. By doing so, one can turn a disempowering concept into an empowering one: consider for example the appropriation of the term 'bitch' by some women, ${ }^{63}$ or the appropriation of the word 'queer' by the gay and lesbian communities. ${ }^{64}$ Appropriation can, of course, also be disrespectful and even harmful: 'cultural appropriation' (or 'misappropriation') by members of a cultural majority of elements of a minority culture is particularly controversial, for example, the use by US sporting teams of Native American tribal names, or the use by commercial organisations of Indigenous Australian names and imagery to sell their products. ${ }^{65}$ In this article, the strategy is intended to be a positive and constructive one in that it involves taking a term being used in a narrow, restrictive sense and redefining and redeploying it with the objective of enhancing the overall wellbeing of the community.

\section{PROFESSIONALISM}

This article calls for the appropriation of the vocationalist notion of 'professionalism'. Professionalism is a vocationalist notion because lawyers are categorised as members of a profession, and it is widely accepted that an important step in preparing law students for employment as lawyers is teaching

60 The Situationists were an international organisation of social revolutionaries made up of avant-garde artists, intellectuals and political theorists. Situationist theory was an attempt to synthesise avant-garde art movements such as Dadaism and Surrealism with anti-authoritarian Marxism into a critique of $20^{\text {th }}$ century advanced capitalism: Sadie Plant, The Most Radical Gesture: The Situationist International in a Postmodern Age (Routledge, 1992).

61 Douglas Holt and Douglas Cameron, Cultural Strategy: Using Innovative Ideologies to Build Breakthrough Brands (Oxford University Press, 2010) 252.

62 See Adbusters, Unswooshing < http://www.adbusters.org/spoofads/unswooshing/>.

63 Stephane Dunn, 'Baad Bitches' and Sassy Supermamas: Black Power Action Films (University of Illinois Press, 2008) 28.

64 Chuck Stewart, Homosexuality and the Law: A Dictionary (ABC-CLIO, 2001) 217.

65 Marianne James, 'Trends \& Issues in Crime and Criminal Justice: Art Crime' (Report No 170, Australian Institute of Criminology, October 2000) <http:/www.aic.gov.au/media_library/publications tandi_pdf/ tandi170.pdf $>$. 
them about the importance of professionalism. The argument goes something like this:

1. A lawyer is a professional.

2. Being a professional requires a capacity for professionalism.

3. Law students should be trained at law school to become lawyers.

4. Therefore, law students should be taught professionalism.

The first two premises are uncontroversial. According to Professions Australia:

A profession is a disciplined group of individuals who adhere to ethical standards and who hold themselves out as, and are accepted by the public as possessing special knowledge and skills in a widely recognised body of learning derived from research, education and training at a high level, and who are prepared to apply this knowledge and exercise these skills in the interest of others. ${ }^{66}$

The practice of law is clearly a profession, and a lawyer is clearly a professional: law is in fact one of the five 'original' professions, along with medicine, divinity, education and armed service. ${ }^{67}$ Professionalism is the competency or skill expected of a professional, and therefore being a legal professional requires a capacity for professionalism.

Some V-sceptics might question the validity of the third premise, that law students should be trained at law school to become lawyers. Most, however, would accept that law schools have an important role to play in the creation of lawyers: recall that it is not the inclusion of vocational elements within the law curriculum that V-sceptics find objectionable, it is the dominance of vocationalism at the expense of competing discourses. The central proposal of this article is that $\mathrm{V}$-sceptics replace the narrow definition of professionalism with a broader, more inclusive definition, one that facilitates achievement of the non-vocational goals sought by the various V-sceptics.

The notion of professionalism is one that is already deeply embedded within contemporary legal education texts and practices. Consider for example the Threshold Learning Outcomes for Law ('TLOs'), the set of learning outcomes all Australian law schools have been strongly encouraged to adopt. TLO 2 is concerned with Ethics and Professional Responsibility:

Graduates of the Bachelor of Laws will demonstrate:

(a) an understanding of approaches to ethical decision-making,

(b) an ability to recognise and reflect upon, and a developing ability to respond to, ethical issues likely to arise in professional contexts,

(c) an ability to recognise and reflect upon the professional responsibilities of lawyers in promoting justice and in service to the community, and

(d) a developing ability to exercise professional judgement. ${ }^{68}$

66 Professions Australia, What is a Profession? (2016) <http://www.professions.com.au/about-us/what-is-aprofessional>.

67 A M Carr-Saunders and P A Wilson, The Professions (The Clarendon Press, 1933).

68 Sally Kift, Mark Israel and Rachael Field, Learning and Teaching Academic Standards Project: Bachelor of Laws Learning and Teaching Academic Standards Statement (Australian Learning and Teaching Council, 2010) 10. See also Maxine Evers, Leanne Houston and Paul Redmond, 'Good Practice Guide 
The law degree is frequently classified as a 'professional degree'. The educational stage between the law degree and admission as a legal practitioner is usually referred to as 'professional legal training' or 'PLT'. Numerous legal education scholars have encouraged their colleagues to embrace the teaching of professionalism. ${ }^{69}$ Yet despite the widespread acknowledgement of the relevance of professionalism to legal education, there is remarkably little consensus about what 'professionalism' actually means in the context of legal education. ${ }^{70}$

At the narrowest end of the spectrum, professionalism is defined as the competency or skill expected of a professional, or as simply the behaviour of a person who satisfies the definition of professional. Eliot Freidson, for example, defines professionalism as follows:

Professionalism may be said to exist when an organized occupation gains the power to determine who is qualified to perform a defined set of tasks, to prevent all others from performing that work, and to control the criteria by which to evaluate performance. ${ }^{71}$

Other narrow approaches to defining professionalism include those that define professionalism in a manner that emphasises a professional's knowledge and expertise in a particular field. Carr-Saunders and Wilson, for example, argue that professionalism is the obligation to the client that exists because the professional knows much more than the client: 'a professional brings asymmetrical knowledge to the service of his client, and thereby exercises power over his client. Therein lie the duties and obligations of a professional to his client'. ${ }^{72}$

Other narrow explanations of professionalism emphasise professional behaviours such as courtesy, punctuality and attention to detail. The MerriamWebster dictionary defines professionalism as 'the skill, good judgment, and polite behavior that is expected from a person who is trained to do a job well' ${ }^{73}$

(Bachelor of Laws): Ethics and Professional Responsibility (Threshold Learning Outcome 2)' (Report, Australian Learning and Teaching Council, 2011).

69 See, eg, John E Montgomery, 'Incorporating Emotional Intelligence Concepts into Legal Education: Strengthening the Professionalism of Law Students' (2008) 39 University of Toledo Law Review 323; William Reece Smith, 'Professionalism? What's That?' (1998) 72 Florida Bar Journal 28; Thomas Gibbons, 'A Realistic Professionalism - the Next Step?' (2010) 18 Waikato Law Review 72; Penfold, 'Teaching Legal Ethics and Professionalism in a South Pacific Context', above n 22; Mary Anne Noone and Judith Dickson, 'Teaching Towards a New Professionalism: Challenging Law Students to Become Ethical Lawyers' (2001) 4 Legal Ethics 127; Annie Rochette and W Wesley Pue, “"Back to Basics?" University Legal Education and $21^{\text {st }}$ Century Professionalism' (2001) 20 Windsor Yearbook of Access to Justice 167; David B Wilkins, 'Redefining the "Professional" in Professional Ethics: An Interdisciplinary Approach to Teaching Professionalism' (1995) 58(3-4) Law and Contemporary Problems 241; Timothy P Terrell, 'A Tour of Whine Country: The Challenge of Extending the Tenets of Lawyer Professionalism to Law Professors and Law Students’ (1994) 34 Washburn Law Journal 1.

70 David B Wilkins, 'Professional Ethics for Lawyers and Law Schools: Interdisciplinary Education and the Law School's Ethical Obligation to Study and Teach About the Profession' (2001) 12 Legal Education Review 47, 47.

71 Eliot Freidson, Professionalism, The Third Logic: On the Practice of Knowledge (University of Chicago Press, 2001) 12.

72 Carr-Saunders and Wilson, above n 68, 49.

73 Merriam-Webster, Professionalism (2016) < http://www.merriam-webster.com/dictionary/ professionalism $>$. 
Former President of the Law Council of Australia, John North, identified the core elements of professionalism as 'the attainment of high levels of skill and judgment, as well as standards of work, ethics and professional conduct'. ${ }^{74}$ Carolyn Penfold recently defined professionalism in terms of what it means to behave unprofessionally, and by contrasting it with unethical behaviour:

For example not returning calls, skipping appointments, or keeping files in disarray, may all be unprofessional while not unethical. Courtesy, organisation, attention to timing, and thorough record keeping may not generally appear to be as important as 'ethics', but where the aim is to increase trust in, respect for, and use of a particular system, and such practice is often not modelled even by senior practitioners or judicial officers, it may need to be more explicitly taught. ${ }^{75}$

It is these narrow versions of professionalism that are often intended when professionalism is identified as a learning outcome of a law program - typically alongside ethics as 'legal ethics and professionalism'. Law students should learn about the ethical rules regulating lawyers' conduct and the importance of treating their clients and their colleagues with courtesy and respect, as well as developing high levels of skill and judgement. They should be honest, ethical and diligent.

Occasionally, however, professionalism is defined more broadly, and it is these broader definitions, as well as the overall uncertainty about what professionalism means in the context of legal education, that can be relied upon in the appropriation of 'professionalism' by V-sceptics. Consider, for example, the notion of professionalism promoted by Roy Stuckey in Best Practices for Legal Education. According to Stuckey, professionalism incorporates: 'a commitment to justice; respect for the rule of law; honour, integrity, fair play, truthfulness and candour; sensitivity and effectiveness with diverse clients and colleagues; and nurturing quality of life' ${ }^{76}$ This goes far beyond an obligation to be courteous and punctual.

Some broader definitions of professionalism emphasise not only a professional's ethical obligations but also their capacity to engage in sophisticated moral reasoning, something that can be used to rationalise the positioning of ethics and morality (and indirectly theories about the relationship between law and ethics) at the heart of any vocational initiative within the law school. An example is the following passage by William M Sullivan:

Legal education .... needs to combine the elements of professionalism conceptual knowledge, skill and moral discernment - into the capacity for judgement guided by a sense of professional responsibility. ${ }^{77}$

Other broader definitions of professionalism emphasise the link between the professional and their community: a professional is not only someone with

74 John North, 'Privilege, Practising Certificates and Professionalism: Where Are the Dividing Fences?' (Speech delivered at the Australian Corporate Lawyers' Association National Conference, 10 November 2005) $4<$ https://www.lawcouncil.asn.au/lawcouncil/images/LCA-PDF/speeches/20051110Privilege practisingcertificates\&professionalism.pdf $>$.

75 Penfold, 'Teaching Legal Ethics and Professionalism in a South Pacific Context', above n 22, 8.

76 Roy Stuckey et al, Best Practices for Legal Education: A Vision and a Road Map (Clinical Legal Education Association, 2007) 62, 79-91.

77 William M Sullivan et al, Educating Lawyers: Preparation for the Profession of Law (Jossey-Bass, 2007) 8. 
specialised knowledge and expertise, but also someone who has an obligation to use that specialised knowledge and expertise for the good of society rather than personal gain. ${ }^{78}$ Lord Benson, as quoted by Spada Limited, insists that ethical standards in a profession 'should be higher than those established by the general law' and 'designed for the benefit of the public and not for the private advantage of the members', and Spada Limited adds that 'it is the duty to serve the public interest which distinguishes a profession from a representative body such as a trade union'. ${ }^{79}$ According to Roscoe Pound:

The term [professionalism] refers to a group of men pursuing a learned art as a common calling in the spirit of public service - no less a public service because it may incidentally be a means of livelihood. Pursuit of the learned art in the spirit of a public service is the primary purpose. ${ }^{80}$

A legal professional is thus someone who is committed to serving the wider community by, for example, ensuring equal access to justice and striving for social justice. ${ }^{81}$ This notion of professionalism legitimates an emphasis upon a lawyer's social obligations and commitment to the public good in any conversation about employability.

Professionalism has also been defined as involving altruism on the part of the professional. George Beaton defines professionalism as 'a combination of knowledge, skills, trustworthiness and altruism found in those who commit themselves to a life of service to others'. ${ }^{82}$ For Beaton, professionals 'express their altruism through serving in networks of responsibility within their profession, often on a volunteer basis' and 'a certain degree of altruism is expected in the true professional, a certain amount of selfless service'. ${ }^{83}$ Similarly Cheetham and Chivers include altruism - defined as being oriented towards service rather than profit - in the list of characteristics that distinguish a profession from a trade. ${ }^{84}$

Scholars in the US have equated professionalism with a commitment to the provision of pro bono services, drawing upon the American Bar Association Model Rule 6.1: 'Every lawyer has a professional responsibility to provide legal services to those unable to pay'. ${ }^{85}$ This is consistent with the definition of

78 George Beaton, 'Why Professionalism is Still Relevant' on Beaton Global (28 January 2010) 13

$<$ http://www.beatonglobal.com/pdfs/GeorgeBeaton_Why_professionalism_is_still_relevant.pdf $>$.

79 Spada Limited, 'British Professions Today: The State of the Sector' (Research Paper, 2009) 3, 38

$<$ http://www.propertyweek.com/Journals/Builder_Group/Property_Week/10_July_2009/attachments/spad a-british-professions-today.pdf $>$.

80 Roscoe Pound, The Lawyer from Antiquity to Modern Times (West Publishing Co, 1953) 5.

81 David B Wilkins, 'Professional Ethics for Lawyers and Law Schools: Interdisciplinary Education and the Law School's Ethical Obligation to Study and Teach about the Profession' (2001) 12 Legal Education Review 47, 47.

82 Beaton, above n 79, 2.

83 Ibid 6.

84 G Cheetham and G Chivers, Professions, Competence and Informal Learning (Edward Elgar Publishing, Inc, 2005) 5-7.

85 John Bliss and Steven Boutcher, 'Rationalizing Pro Bono: Corporate Social Responsibility and the Reinvention of Legal Professionalism in Elite Law Firms' (Paper presented at Law and Society Association Annual Meeting, New Orleans, 2-5 June 2016). Bliss and Boutcher argue that many large law firms are rationalizing their pro bono activities not in terms of professional responsibility but instead in terms of corporate social responsibility. 
professionalism as involving a commitment to the public good or public service. Such a definition can be used by $\mathrm{V}$-sceptics to rationalise an emphasis upon the issue of access to justice in the vocationalised law curriculum, as well as the encouragement of law students to engage in pro bono work while at law school and the establishment of pro bono teaching clinics by the law school. ${ }^{86}$

Fruehwald distinguishes between professionalism and professional identity. Professionalism is defined narrowly as the ability to act in a professional manner, and involves 'politeness, thoroughness, and getting work done on time'. The broader, more inclusive notion of professionalism is renamed 'professional identity' and includes 'a lawyer's personal legal morality, values, decisionmaking process, and self-consciousness in relation to the practices of the legal profession' ${ }^{87}$

Hall et al similarly favour the notion of professional identity. ${ }^{88}$ They begin their examination of professional identity formation citing Floyd:

The administration of justice would be improved if, instead of thinking only about what we want lawyers to know and what we want them to be able to do, we thought instead about who lawyers should be when they graduate from law school. ${ }^{89}$

They criticise the aspects of professional identity formation emphasised by traditional approaches to teaching law: thinking like a lawyer, adversarialism, and individualism. Such a narrow approach to conceptualising professional identity should be replaced by the broader approaches described above. Hall et al call for a re-envisioning and reinvention of legal education by shifting the emphasis in professional identity formation in favour of empathy and resilience. ${ }^{90}$ Such a shift in emphasis would justify the inclusion within the vocationalised law curriculum of time spent developing law student emotional intelligence as well as strategies to address law student psychological distress. ${ }^{91}$

These and similarly inclusive notions of what it means to be a professional allow V-sceptics to appropriate and redefine the notion of 'professionalism' and thus begin to steer vocationalism in a different direction.

\footnotetext{
86 Cantatore, above $\mathrm{n} 23$.

87 Scott Fruehwald, 'An Introduction to Professional Identity Development for Law Students' (2016) $<$ http://ssrn.com/abstract=2753139>.

88 Kath Hall, Molly Townes O’Brien and Stephen Tang, 'Developing a Professional Identity in Law School: A View from Australia' (2010) 4 Phoenix Law Review 21.

89 Ibid, quoting Daisy Hurst Floyd, 'Lost Opportunity: Legal Education and the Development of Professional Identity’ (2007) 30 Hamline Law Review 555, 556.

90 Hall, Townes O'Brien and Tang, above n 89, 25-30.

91 See Penelope Watson and Rachael Field, 'Promoting Student Wellbeing and Resilience at Law School' in Sally Kift et al (eds), Excellence and Innovation in Legal Education (LexisNexis Butterworths, 2011); Susan Douglas, 'Incorporating Emotional Intelligence in Legal Education: A Theoretical Perspective' (2015) 9(2) e-Journal of Business Education and Scholarship of Teaching 56; Colin James, 'Lawyer Dissatisfaction, Emotional Intelligence and Clinical Legal Education’ (2008) 18 Legal Education Review 123.
} 


\section{APPROPRIATING PROFESSIONALISM}

This article proposes that $\mathrm{V}$-sceptics reconsider their explicit criticism of and opposition to vocationalism in favour of lobbying for the adoption of a more inclusive, strategically defined notion of professionalism by their law schools. While this article does not advocate any particular definition of professionalism, an example may be useful:

A legal professional (1) has a specialised understanding of not only legal rules, principles and doctrines but also law's theoretical and ideological foundations and its historical, cultural, social and political contexts; (2) is able to engage in both legal and ethical reasoning, and think critically about the law's role in society and its practical impact upon various communities and individuals; and (3) is altruistic, trustworthy, honest, and committed to ethical legal practice, social justice, and the public good.

This definition describes the 'knowing, acting and being' associated with being a professional, and can easily be used to develop appropriate learning outcomes for a law curriculum. ${ }^{92}$ By adopting and strategically promoting such an expanded notion of professionalism, those concerned about or opposed to vocationalism's dominance can appropriate a concept that is close to the heart of the vocationalist agenda. Very few proponents of vocationalism would deny the importance of facilitating the transformation of law students into legal professionals. However, by defining professionalism in a broader and more inclusive way, the relocation back to the heart of the curriculum of previously marginalised or disregarded perspectives on the law becomes justifiable in vocational terms. Students should learn about social justice, gender equity, legal history, legal culture and so on because they are part of the effort to support the development by students of a professional identity. By learning these things students are more likely to recognise the responsibilities of lawyers beyond being productive employees, including their responsibility to social justice and the public good. Even where the 'professionalisation' of law students is limited to ensuring that they graduate with the knowledge and skills required to practice law as an employee solicitor, an appropriated notion of professionalism will encourage the consideration by law students of a range of possible careers beyond employment by a large law firm.

The appropriation of professionalism has the potential to address the four main criticisms of vocationalism's dominance described earlier:

1. Loss of theoretical rigour - Defining professionalism to include 'a specialised understanding of not only legal rules, principles and doctrines but also law's theoretical and ideological foundations' justifies the reintroduction of an emphasis upon both legal doctrine and legal theory into the curricula of some subjects. If professionalism includes an appreciation of the content, theory and philosophy of law, space within the compulsory curriculum must be set aside for an examination of the minutiae of law's content and the framing of that examination within

92 Gloria Dall'Alba, 'Improving Teaching: Enhancing Ways of Being University Teachers' (2005) 24 Higher Education Research and Development 361. 
jurisprudential, interdisciplinary, political or sociological contexts. We should be wary, of course, of a return to doctrinalism's dominance, but an explicit linking of doctrinal analysis with that doctrine's theoretical foundations will ensure this does not occur.

2. Loss of curricular breadth - If professionalism includes an understanding of law's historical, social and cultural contexts, and an appreciation of the intimate relationships between law, justice, ethics and politics, Vsceptics can justify the broadening of the curriculum beyond an emphasis upon employability in terms acceptable to those who prioritise employability.

3. Over-emphasis upon extrinsic motivation - When the student is driven by the goal of employment, they can find themselves in the position of doing something they neither understand nor enjoy today in order to possibly achieve a desired outcome tomorrow. This is a position that can provoke considerable discomfort and anxiety. By shifting the focus away from employment in favour of professionalism, the student's focus becomes who they are and who they are becoming today, rather than the distant goal they are working towards. The conditions are created for the students to adopt intrinsic motivators rather than purely extrinsic motivators. The students can see that what they are learning at law school is transforming their character and their being in a positive way. This has the potential to be a much healthier attitude for the student.

4. Favouring the social and political status quo - Professionalism includes a commitment to the public good, which itself entails an appreciation of law's shortcomings as well as its benefits, a capacity to criticise the law, and a willingness to, where appropriate, engage in legal and social reform. Emphasising professionalism within the curriculum is a way to avoid the law school devoting excessive time and resources to producing graduates who are merely work ready, and to instead commit to producing graduates who are critics, reformers and agents for change.

It is gratifying that the appropriation and redefinition of professionalism seems to already be taking place in various locations within the Australian legal education landscape. Reference has already been made to recent developments in clinical legal education, and it is in this space that considerable efforts are being made to reconcile the vocationalist emphasis upon practical legal skills and experience with the loftier ideals of commitment to the public good, access to justice, social justice, altruism and non-adversarial approaches to dispute resolution. A number of Australian law schools already collaborate with local community legal centres to offer pro bono teaching clinics, including the law schools at Monash University, Murdoch University, Newcastle University, Bond University and the University of New South Wales. ${ }^{93}$ These clinical programs, as

93 Kingsford Legal Centre, 'Clinical Legal Education Guide' (2016) < http://www.klc.unsw.edu.au/sites/ klc.unsw.edu.au/files/2676\%20CLE\%20guide_WEB.pdf>; Adrian Evans et al, 'Best Practices Australian Clinical Legal Education' (Report, Australian Government Office for Learning and Teaching, 2012). 
well as some of the more progressive PLT programs, ${ }^{94}$ are striving to transform law students into legal professionals in the broader rather than the narrower sense of the term.

The appropriation of 'professionalism' proposed in this article does not mean that the competing discourses are subsumed within vocationalism. Rather, by creating a point of cooperation between those supportive of vocationalism and those opposed to vocationalism's dominance, the appropriation provides the proponents of competing discourses with a strategy to achieve their preferred outcomes, and is thus a mechanism for reducing vocationalism's dominance of contemporary legal education and shifting the balance back in favour of some of the other discourses. Even if the vocational insistence upon the importance of employability and preparation for professional practice is accepted, the appropriation and redefinition of professionalism as described in this article is essential. Susan Daicoff argues that the legal profession is undergoing a widespread and fundamental transformation, which she labels the comprehensive law movement. She identifies nine new approaches to law, lawyering, dispute resolution and adjudication that fit within this movement: therapeutic jurisprudence, preventive law, holistic law, procedural justice ('social science research on litigants' satisfaction with and perceptions of the fairness of legal processes'), creative problem-solving, collaborative law ('a non-litigious means for resolving divorce and custody cases with two attorneys, two clients and possibly an interdisciplinary team of experts'), transformative mediation ('dispute resolution focused on moral growth of the parties'), restorative justice ('an approach to crime focused on healing through conferencing between victims, offenders and society'), and problem-solving courts ('such as drug treatment courts, courts for homeless persons, domestic violence courts, etcetera'). ${ }^{95}$ These approaches share an emphasis upon consideration of parties' needs, desires, goals, mental status, wellbeing, relationships and future functioning, and upon optimisation of the outcomes of legal matters 'as measured by human wellbeing, by assessing the effects of law and legal processes on the 'human element' (meaning emotions, psychological functioning and relationships involved in legal matters) ${ }^{9} .{ }^{96}$ According to Daicoff and others, ${ }^{97}$ the comprehensive law movement has established its credibility and viability, and the focus is now turning to the implications of the movement for law schools and legal education. The broader notion of professionalism described in this article will do far more to prepare law students for this new paradigm of

\footnotetext{
94 Stephen Tang and Anneka Ferguson, 'The Possibility of Wellbeing: Preliminary Results from Surveys of Australian Professional Legal Education Students' (2014) 14 QUT Law Review 27, 46.

95 Susan Daicoff, above n 41, 19.

96 Ibid.

97 Daicoff cites Susan L Brooks and Robert G Madden, Relationship-Centered Lawyering: Social Science Theory for Transforming Legal Practice (Carolina Academic Press, 2010), J Kim Wright, Lawyers as Peacemakers: Practicing Holistic, Problem-Solving Law (American Bar Association, 2010), Michael King et al, Non-Adversarial Justice (The Federation Press, 2009), Julie Macfarlane, The New Lawyer: How Settlement Is Transforming the Practice of Law (UBC Press, 2008), and Marjorie A Silver, The Affective Assistance of Counsel: Practicing Law as a Healing Profession (Carolina Academic Press, 2007).
} 
professional legal practice than the traditional narrow emphasis upon teaching law students how to think like a lawyer, exercise practical legal skills, behave courteously and comply with professional conduct rules.

\section{CONCLUSION}

This article is not suggesting that the appropriation of professionalism provides a solution to the conflict between competing discourses within legal education. That conflict between discourses is a good thing. Healthy law schools and healthy disciplines are characterised by ongoing debate between different ideologies: the conversation must continue. ${ }^{98}$ The expanded notion of professionalism does, however, provide a potential 'common ground', a point at which those allied to different discourses can come together. When professionalism is defined appropriately, the doctrinalists, the liberals, the educationalists and even the radical legal theorists can work together to embed the development of professionalism and a professional identity within the law school curriculum, and unite in the teaching and assessment of law students' ability to behave professionally and be professionals.

The expanded notion of professionalism advocated in this paper also provides legal academics with an answer to the question 'Why on earth is this topic on [theory/history/culture/politics/gender/race/etc] included in the curriculum? It has nothing to do with legal practice!' This question may be asked by students, by university administrators or by other stakeholders. In either case, the response can now be to the effect that these topics are included in the curriculum because an understanding of these topics is an essential element of being a professional in the wider sense of the word. This is an answer that even the staunchest vocationalist can be persuaded to accept.

V-sceptics who are concerned about the apparently unstoppable train of vocationalism moving though contemporary legal education, and who wish to do something about it, have a number of options available to them. They can ignore the train. They can throw stones at the train. They can lay down on the tracks in front of the train. It is unlikely that any of those options will be terribly effective. Alternatively, those opposed to vocationalism's dominance can do as this article suggests. They can climb on board the train ... and hijack it.

98 Nickolas John James, 'Australian Legal Education and the Instability of Critique' (2004) 28 Melbourne University Law Review 375, 380. 